\title{
A CASE OF PRIMARY MELANO-CARCINOMA OF THE CILIARY BODY
}

BY

\author{
R. H. Balfour Barrow and H. B. Stallard
}

LONDON

PRIMARY melano-carcinoma of the ciliary body is a very rare disease, and hitherto only a few cases have been reported in the literature.

On January 16, 1931, H.S., a blacksmith, aged 61 years, presented himself for examination on account of defective right vision. For a month he had noticed that the right vision was hazy, and had become steadily worse. Two years ago his visual acuity was recorded as follows :-Right vision with $+0.5 \mathrm{sph}$. and $+0.5 \mathrm{cyl}$. $\rightarrow^{\prime} 180^{\circ}=6 / 6$, left vision with $+1^{\circ} 0 \mathrm{sph}$. and $+1.0 \mathrm{cyl} . \rightarrow 180^{\circ}=6 / 9$. The fundi were normal at this time.

Fig. 1 is a diagram representing the clinical appearance of a swelling situated on the iris and in the filtration angle at six o'clock. The summit of the swelling impinged upon the posterior aspect of the cornea, and the greater part of it was of a greyish brown colour, except in the filtration angle where it had a "pearly" appearance with two small vessels running over its anterior surface. Some of the anterior ciliary vessels at six o'clock were dilated and engorged with blood. The swelling did not extend to the free margin of the iris. The reaction of the pupil to direct light was sluggish, but the consensual reaction brisk. The pupil dilated well with homatropine, and it was impossible to detect by clinical methods any neoplasm in the ciliary body. The lens was opaque in the vicinity of the neoplasm, and the opacity had spread upwards to the pupillary area. The intra-ocular pressure was normal and there was no evidence of an inflammatory lesion in the eye.

A general examination failed to reveal a neoplasm elsewhere in the body. The patient was in good health and had no symptoms or loss of weight. The Wassermann reaction was negative. $\mathrm{He}$ was admitted to the Moorfields Eye Hospital, and a clinical diagnosis of sarcoma of the ciliary body and iris was agreed upon. Excision was advised and performed.

\section{Pathological Report}

(a) Macroscopic.-Situated in the iris and ciliary body at six o'clock is a neoplasm $3.5 \times 3 \mathrm{~mm}$. It is raised above the level of the anterior surface of the iris; the surface is nodular and impinges on the posterior aspect of the cornea. The colour is greyish white, except at the periphery where there is some dark brown pigment. 


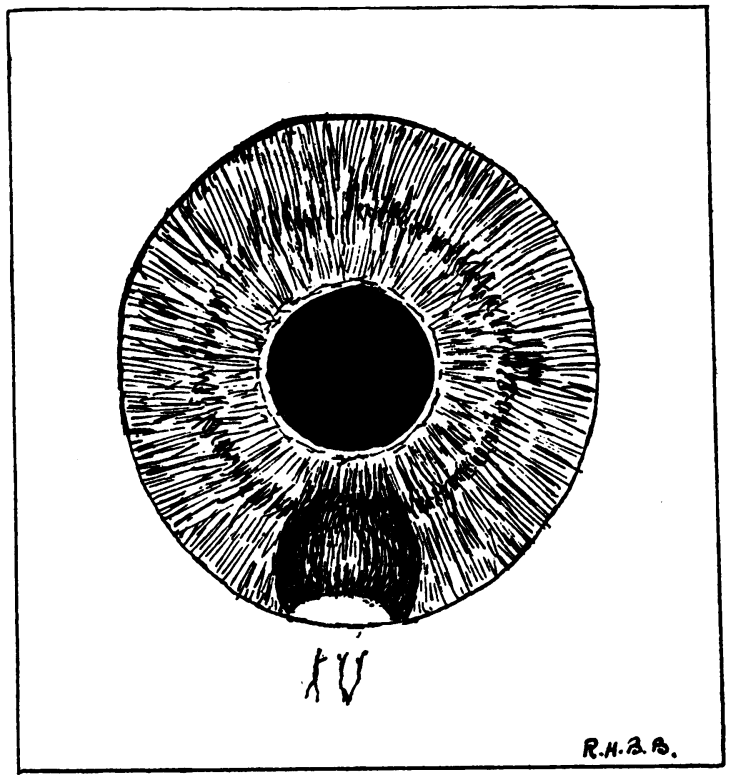

FIG. 1.

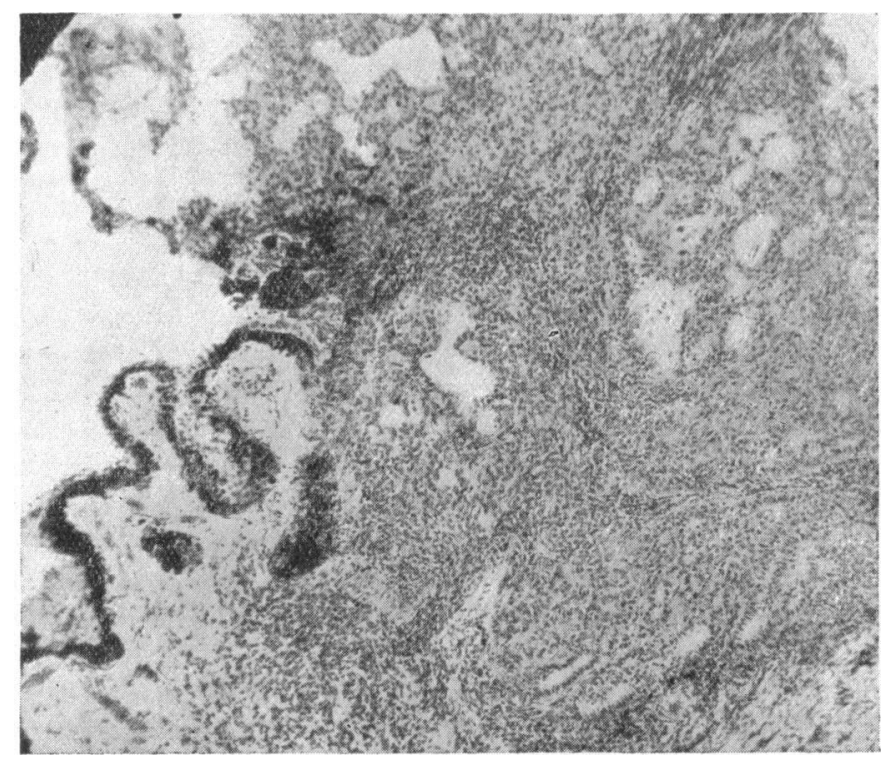

FIG. 2. 
The cut surface of the neoplasm presents a stippled appearance of white dots on a grey background, and with a loupe some areas of myxomatous degeneration are visible. The consistence is soft elastic. The pars iridica retinae and the ciliary epithelium have been penetrated by the neoplasm, which has pressed upon the lens at the equator and produced a capsular cataract.

(b) Microscopic.-Fig. 2 is a microphotograph which shows the neoplasm arising from the ciliary epithelium and infiltrating the ciliary body. At the periphery the cells are arranged in rows of short cubes and resemble those of the ciliary epithelium, some are pigmented and others non-pigmented. In the centre of the neoplasm the cells are disposed irregularly. There are areas of hyaline, colloid, and myxomatous degeneration, also cystic spaces lined by pigmented epithelial cells (see Fig. 4) and containing hyaline material and degenerated cells, some of which are very swollen. Lymphocytes are present at the advancing edge of the neoplasm, and some are aggregated into large clumps amongst the tumour cells. Mitosis is evident in some of the cells of the neoplasm.

Fig. 3 is a microphotograph of the filtration angle at six o'clock. It shows the root of the iris infiltrated by the neoplasm which is pressing against the ligamentum pectinatum and occluding the filtration angle. The canal of Schlemm and the wall of a tributary from the deep scleral plexus of veins were also invaded. At one site

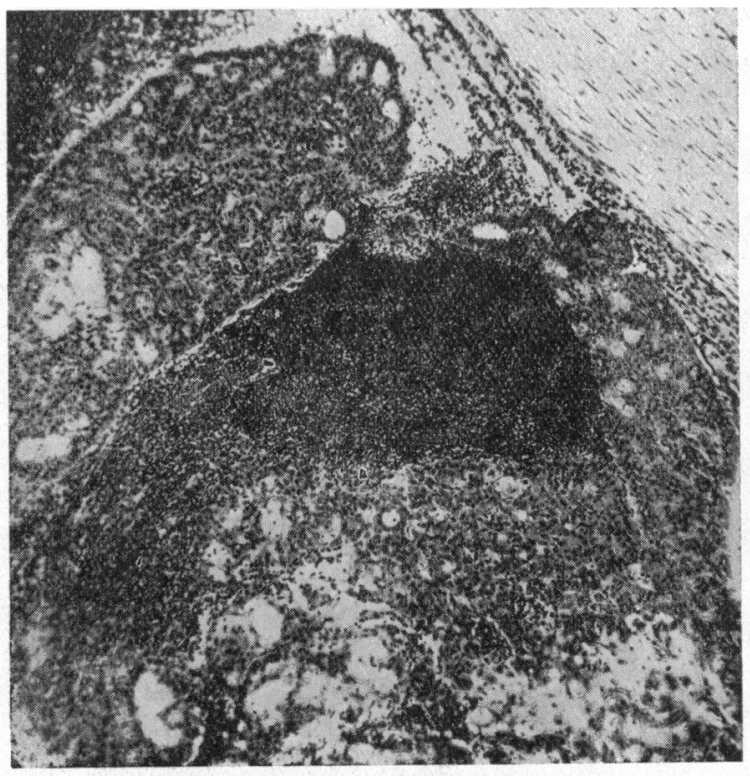

Fic. 8. 
the endothelium was stripped from Descemet's membrane, and the intervening space filled by cells from the neoplasm.

The blood vessels at the site of the neoplasm were dilated and congested. Hyaline degeneration had taken place in the loose connective tissue beneath the ciliary epithelium and in the vicinity of the neoplasm, and also in the tunica media of the iris vessels.

Some pigment and red blood corpuscles were adherent to the posterior aspect of the cornea.

Fig. 4 is a microphotograph taken at the point where the neoplasm has penetrated the pars iridica retinae and pressed upon

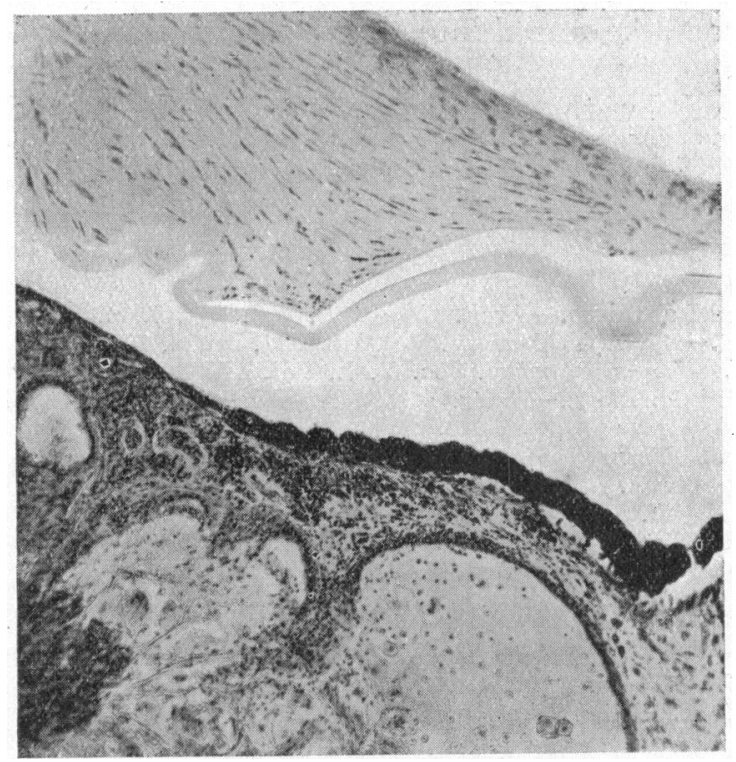

Fig. 4.

the lens capsule. The hyaline layer of the capsule is rucked up and presents a wavy outline. The epithelial layer has undergone metaplasia and formed a capsular cataract. In the stroma of the iris some cystic spaces are seen. These are lined by short cubical epithelial cells placed side by side. The contents are hyaline material, cell débris, and some large swollen cells with vacuolated cytoplasm.

A pathological diagnosis of primary melano-carcinoma of the ciliary body was made.

\section{Literature}

A survey of the literature revealed the rarity of this condition. The age incidence varies from 10 (Greeves' case) to 69 (Snell's case). The authors of the cases reported in the literature have 
commented on the following histological appearances; the epithelial nature of the neoplasm and the arrangement of the cells in rows, columns, and in some instances the resemblance to a glandular structure with a central lumen. Colloid degeneration is described and observations made about the comparative avascularity of these neoplasms. Pigment was present in some cases, and was absent or had disappeared in others. A history of previous injury and defective vision was given in several instances. In some cases the pupil was described as being irregular. Displacement of the lens, opacities, and fosette formation from contact with the neoplasm are mentioned by Greeves and other authors. The origin of the neoplasm could be traced into the unpigmented layer of the ciliary epithelium. The root of the iris, ciliary body, and filtration angle were invaded by the neoplasm. Comment is made by some observers that after excision of the affected eye, recurrence of the neoplasm does not occur.

\section{REFERENCES}

1. Badal and Lagrange.-Arch. d'Ophtal., Vol. XII, p. 143, 1892.

2. Fuchs, E.-Arch.f. Ophthal., Vol: LXVIII, p. 534, 1908.

3. Greeves.-Trans. Ophthal. Soc. U.K., Vol. XXXI, p. 261, 1911.

4. Kuthe and Ginsberg.-Beitr. z. Augenheilk. Festschr.f. Hirschberg, p. 127, 1905.

5. Lagrange.-Tumeurs de l'Oeil., Vol. I, 1901.

6. Märtens.-Arch.f. Augenheilk., Vol. LXXXIX, p. 1, 1921.

7. Meller.-Arch.f. Augenheilk., Vol. LXXXV, p. 151, 1913.

8. Parsons. - Pathology of the Eye, Vol. I, p. 361.

9. Snell.-Trans. Ophthal. Soc. U.K., Vol. XIX, p. 99, 1899.

10. Collins, Treacher.-Trans. Ophthal. Soc. U.K., Vol. XI, p. 61, 1891. Researches, 1896.

11. Velhagen.-Klin. Monatsbl. f. Augenheilk., Vol. LVIII, Part I, p. 239, 1917.

12. Verhoeff.- Trans. Amer. Ophthal. Soc., 1904.

13. Wunderlick.-Klin. Monatsbl.f. Augenheilk., Vol. LXVI, Part I, p. 217, 1921.

\section{AN ELECTRIC OPHTHALMOSCOPE}

BY

\section{N. BISHOP HARMAN}

LONDON

THE optical part of this ophthalmoscope was shown to the Ophthalmological Society of the United Kingdom in 1904, a description of the mechanism was given in the Lancet, Vol. LXXXI, p. 28, 1905.

Recently, Messrs. Rayner (who had acquired the original patterns) asked me if I would supervise the adaptation of the original reflecting ophthalmoscope to a self-contained electric fitting. 